\title{
Distribution and current vegetation of Cakile edentula, an invasive alien species in Korea
}

Tae-Bok Ryu, Dong-Hui Choi, Deokki Kim, Jung-Hyo Lee, Do-Hun Lee and Nam-Young Kim * (D)

\begin{abstract}
Background: Cakile edentula (Bigelow) Hook. is a successful invader that has been propagating globally. In Korea, Cakile edentula was found in 2008 for the first time, in the east coast of Korean peninsula. Based on site surveys conducted thereafter, Cakile edentula has propagated in the east coast from Goseong to Jeongdongjin, Gangneung and in the west coast of city of Hwaseong of Gyeonggi-do Province, and Taeangun County of Chungcheongnam-do Province.

Results: Cakile edentula has infiltrated into four different vegetation communities (syntaxa) (Calystegio soldanellaeSalsoletum komarovii Ohba, Miyawakiet Tx.1967; Elymo-caricetum Kobomugi Miyawaki 1967; Carex pumila; and Calystegia soldanella) belonging to phytosociological classes of saltwort (barilla) and coastal glehnia. Cakile edentula competes with dominant species such as the saltwort (barilla) and beach morning glory, causing qualitative changes in species composition. It also affects local ecosystems through its competition with indigenous species, causing destruction of the traditional landscape.

Conclusions: However, competition of Cakile edentula with indigenous species and the resulting replacement of such species are limitedly reported. Potential competitors with Cakile edentula have not been found yet. In Northeast Asia, qualitative changes realized in local ecosystems due to invasion of Cakile edentula are significantly noticeable. These necessitate proper controls for this invasive alien species to protect and preserve coastal dune areas.
\end{abstract}

Keywords: Invasive alien plants, Alien species, Current vegetation, Preserve coastal dune areas

\section{Background}

Cakile (CAKILE Miller, Gard. Dict. Abr., ed. 4. 1754.) is a genus of annual or perennial herbs belonging to the family Cruciferae of which seven species are currently growing in the northern hemisphere (Rodman 1974; Rollins 1993). Among them, Cakile edentula (Cakile edentula (Bigelow) Hook.) is an important constituent species in coastal dune vegetation (Taira and Hiroko 2006). It is distributed over the coast of North America (Barbour and Rodman 1970; Maun et al. 1990). Depending on environmental gradient, zonal distribution of Cakile edentula extends from the forefront of coastal dunes to stabilized sand dunes. Alien plants invading disturbed habitats are characterized by high productivity and propagation power (Baker 1965; Harper 1977).

\footnotetext{
* Correspondence: nykim@nie.re.kr

Division of Ecological Conservation Bureau of Ecology Research, National Institute of Ecology, Seo-Cheon Gun, Chungcheongnam Province 325-813, South Korea
}

Cakile edentula shows high seed production, short cycle of growth and development, and high rate of settlement (Maun et al. 1990). Coastal sand dune is a habitat exposed to natural or artificial disturbances attributable to moving sands, sea waves, winds, human interference, and so on (Chapman 1976) where a range of dominant and expanding vegetations of Cakile edentula are frequently found. Currently, the vegetation of Cakile edentula has been propagated in Japan (Asai 1983; Fukuda et al. 2013), Australia (Rodman 1986; Cousens et al. 2013), New Zealand (Cousens and Cousens 2011), and the West and Atlantic coasts of North America (Barbour and Rodman 1970). Invasion of Cakile edentula has negative effects such as competition with Cakile maritima or destruction of traditional landscape (Barbour and Rodman 1970; Rodman 1974). In some places, invasive alien plants could become sources of qualitative changes in indigenous local ecosystems (Kiyosue and Asai 2009; Cousens and Cousens 2011). 
In Korea, the presence of Cakile edentula in the shore of the east coast of Gangneung City was first reported in 2008 (Kil and Lee 2008). The environmental characteristics of the original habitat are the same as our Korean environment. Despite the ecological and scenic importance of costal sand dunes, no subsequent studies delving into issues related to Cakile edentula have been reported. Available information on ecological problems of Korean coastal sand dunes related to or attributable to the invasion of Cakile edentula is limited.

The objective of this study was to determine geographical distribution and ecological vegetation of Cakile edentula in Korea. Besides, vegetation of Cakile edentula was compared to indigenous vegetation in Korea to examine changes in species composition of coastal dunes due to the invasion of Cakile edentula and identify similarity in vegetation of Cakile edentula compared to those in the community of Cakile edentula that invaded Japanese coastal vegetation in Northeast Asia. Results obtained from this study will clarify ecological issues related to coastal dune vegetation. They might contribute to the control and restoration of coastal dune vegetation in Northeast Asia.

\section{Methods}

Geographically, Korea resides in the peninsula in Northeast Asia surrounded by the East Sea, Yellow Sea, and South Sea (Fig. 1). Annual average temperature and annual precipitation in Korea are $6.6-16.6{ }^{\circ} \mathrm{C}$ and $825.6-2007.3 \mathrm{~mm}$, respectively (KMA 2012, 2017). The peninsula belongs to the area of temperate climate monsoon characterized by hot and humid summers and cold dry winters dominated by continental climate of wide daily temperature range (KMA 2012; Kim and Lee 2006). The east coast of Korean peninsula facing the East Sea is characterized by its straight line while the coast lines of the South and Yellow Sea are characterized by complex shapes developed by the formation of ria coasts. There are approximately more than 133 coastal dunes in Korea. They are observed more frequently from the coasts of the Yellow and South Sea (Yoon et al. 2010). Some coastal dunes of over $2 \mathrm{~km}$ in respective length are protected as national parks. However, most coastal dunes are damaged by human interferences such as seaside resorts, wharfs, and amusement facilities. This study was designed to examine coastal dunes in Korea where invasive alien Cakile edentula was found.

Bibliographic investigation on existing literature and studies was conducted to obtain information from various websites to identify distribution of Cakile edentula. Through preliminary investigation, the East Coast of Gangwon-do Province and the West Coast of Chungcheongnam-do Province and Gyeonggi-do
Province have growth of Cakile edentula (Fig. 1). Subsequent site surveys were conducted during MarchOctober 2016 following coastal lines of the Yellow and East Sea. For these surveys, sites of habitats where Cakile edentula growed individually or collectively were selected. To identify the distribution of Cakile edentula, the size of population in respective habitats, latitude and longitude thereof, altitude above sea level, and azimuth were investigated. Values of latitude and longitude were obtained from Global Positioning System (GPS) measurements.

To examine vegetations, phytosociological methods with emphasis on species composition and types of habitats (Westhoff and van der Maarel 1978) described by the school of Zürich-Montpellier (Z.-M.) (Braun-Blanquet 1965) were used in this study to examine each site invaded by Cakile edentula.

A total of 19 vegetation survey sheets (phytosociological relevé) were collected from 29 sites in the East Coast. The west coast of the Korean peninsula was excluded from the site survey because the distribution of Cakile edentula there was concluded to be in the introductory stage of invasion. To extract units of vegetation (syntaxa), the integrated classification involving a combination of traditional methods of classification of the Z.-M. school (Becking 1957 ) with those of numerical statistical analysis was used as described previously (Kim and Lee 2006).

Relative net contribution degree ( $r-\mathrm{NCD})$ values of extracted units of vegetation were then comparatively analyzed using the 64 vegetation survey sheets (phytosociological relevé) of coastal dunes in Korea that were free from invasion of Cakile edentula (Han 2012).

The value of r-NCD obtained from integrated consideration of quantitative (coverage) and qualitative (frequency) contribution of the newly appeared species to existing plant community is regarded as an accomplishment of reliability evaluation (Kim and Manyko 1994). Cases of vegetation in Japanese coastal dunes invaded by Cakile edentula were also examined (Taira and Hiroko 2006). Previous studies containing information of habitats and units of vegetation according to the International Code of Phytosociological Nomenclature (Weber et al. 2000) were used.

\section{Results and discussion}

Present distribution and characteristics of Cakile edentula Vegetation of Cakile edentula was found on the east coast of the Korean peninsula ranging from the Anmok Beach, Gangneung City, to the Hyanghori Beach of Jumunjin (currently, the Donghae City) for the first time in 2008 (Kil and Lee 2008). Results obtained from site surveys conducted in this study showed that the distribution of vegetation of Cakile edentula extended from the beach of Jeongdongjin, Gangneung City, to the north 


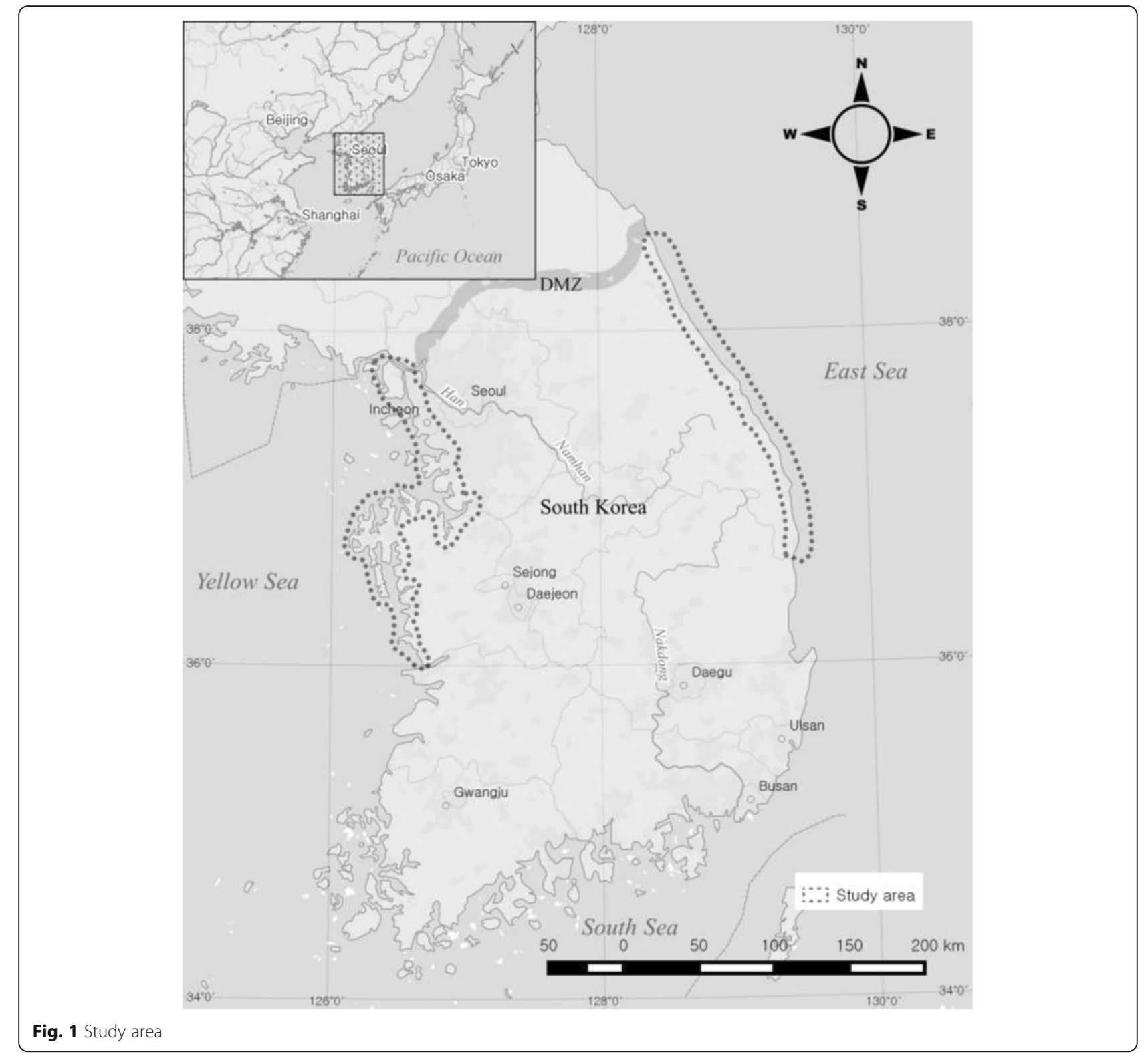

of Goseong County, Gangwon-do Province. The size of the population of Cakile edentula increased more at the region above $38^{\circ}$ of northern latitude whereas the size thereof decreased southbound (Fig. 1).

It seems the vegetation of Cakile edentula is rapidly growing south along the coastal dunes formed in the east coast of the Korean peninsula. Based on previous studies showing that Cakile edentula has invaded the west coast of North America and propagated at a rate of 40 miles a year (approx. $64 \mathrm{~km}$ ) (Barbour and Rodman 1970), the vegetation in the east coast of the Korean peninsula is propagating more rapidly. In the west coast of the Korean peninsula, the vegetation of Cakile edentula was found in three places: the beach of
Goongpyeong-ri, Hwaseong City; the beach of Hwangchon-ri, Wonbukmyeon, Taean County, Chungcheongnam-do Province; and the beach of Jebu-ri, Seoshinmyeon, Gyeonggi-do Province. They are currently at the introductory stage in each region (containing three to four individuals). Thus, their effects on local ecosystem are insignificant.

The invasion of Cakile edentula in Japan was first reported from Niigata Prefecture, Honshu, in 1981 (Asai 1983). It then propagated in Hokkaido and the Kuril Islands. Vegetation of Cakile edentula in coastal dunes facing the Pacific Ocean, in Fukushima Prefecture and Ibaraki Prefecture, as well as in the coastal dunes facing the East Sea has been reported (Taira and Hiroko 2006). 
Seeds of Cakile edentula can float on water for 10 weeks and exposed seeds thereof may germinate (Rodman 1974). However, the vegetation of Cakile edentula found in Korea and Japan might not be directly introduced from its origin. Rather, the infiltration of Cakile edentula found in Korea is directly attributable to ballast water of ships or indirectly ascribable to ocean current flown from the Japanese coast.

\section{Current vegetation of Cakile edentula in Korea}

Cakile edentula grows either in annual herbaceous communities of coastal drift line developing above high-water line or in herbaceous vegetation developing in coastal sand dunes.

Phytosociologically, Cakile edentula can infiltrate into the vegetation of saltwort (barilla) (Salsoletea komarovii Ohba, Miyawaki et Tx. 1973), the top unit of vegetation of coastal drift-line in Northeast Asia, and into vegetation of coastal glehnia (Glehnietea littoralis Ohba, Miyawaki et Tx. 1973), the top unit of herbaceous vegetation of coastal dune.

Among them, Cakile edentula was found in the following four units of vegetation (syntaxa): beach morning glory-saltwort (barilla) community (Calystegio soldanellae-Salsoletum komarovii Ohba, Miyawakiet Tx.1967), sea wheatgrass-Asian sand sedge community (Elymo-caricetum Kobomugi Miyawaki 1967), dwarf sand sedge community (Carex pumila community), and beach morning glory community (Calystegia soldanella community) (Table 1).

The beach morning glory-saltwort (barilla) community belonging to the class of saltwort (barilla) (Salsoletea komarovii Ohba, Miyawaki et Tx. 1973) develops at the forefront site of coastal lines where organic substances inflowing from the sea are accumulated (Tüxen 1973; Masanori 1996; Hayasaka and Fujiwara 2006. Han 2012).

Saltwort (barilla) and beach morning glory are characteristic species of the community that develop in the entire east coast of the Korean peninsula (Han 2012).

Cakile edentula shows the highest coverage (at least more than 25\%). In communities infiltrated by Cakile edentula, qualitative changes such as changed coverage of diagnosed species group of beach morning glory were found (Table 2).

In particular, increase of beach morning glory that prefers eutrophicated sites indirectly shows increase of nitrogen content and organic substances attributable to increasing population of Cakile edentula.

Owing to changes in environmental elements at sites, invasive alien plants such as evening primrose (Oenothera biennis), American dodder (Cuscuta pentagona), buttonweed (Diodia teres), common ragweed (Ambrosia artemisiifolia), and cocklebur (Xanthium canadense) that are not components of the original coastal vegetation can cause qualitative changes in species composition.
In Japan, the vegetation community of Cakile edentula-saltwort (barilla) generated in the same site condition was recorded (Taira and Hiroko 2006).

In the three units of vegetation of coastal glehnia developing at the foredune, effects due to invasion of Cakile edentula seem to be comparatively less in distribution frequency and dominance.

However, in the sea wheatgrass-Asian sand sedge community (Elymo-caricetum Kobomugi Miyawaki 1967), a representative coastal herbaceous vegetation of subpolar zone in the Northeast Asia as well as the one of important units of vegetation in the east coast of Korean peninsula (Jung and Kim 1998), Asian sand sedge and sea wheatgrass dominate there while Cakile edentula occupies approximately $12 \%$ in coverage depending on site conditions.

Changes in species composition in the communities such as decreased sea wheatgrass and beach morning glory and increased coastal glehnia, creeping beach ixeris, and dwarf sand sedge were detected.

Besides, depending on site conditions, Cakile edentula showed sole coverage or less than $10 \%$ of its coverage in the communities of beach morning glory and dwarf sand sedge. Natural or artificial disturbances in coastal area might have acted as a factor promoting the infiltration of Cakile edentula. After infiltration of Cakile edentula into the natural or quasi-natural coastal vegetation, it then competes with indigenous species therein.

Long-range monitoring enabled tracing of changes in vegetation of Cakile edentula. Such changes have negative effects by destroying indigenous landscapes. Qualitative changes in species composition of the vegetation on coastal dune need to be determined.

\section{Coastal vegetation in Northeast Asia and Cakile edentula}

Various ecological problems resulting from Cakile edentula escaped from its origin, such as its infiltration into new habitat, competition therein, and replacement of the species such as $C$. maritima belonging to identical genus, have been reported (Barbour and Rodman 1970; Rodman 1974).

Due to unintentional factors such as those associated with ballast water of ships, Cakile edentula is propagating globally.

Alien plants typically show high rate of infiltration into climatic zones corresponding to climatic range of its original habitat (Harper 1965; Mulligan 1965). The subpolar zone in the Northeast Asia is similar to the climatic zone of the original habitat of Cakile edentula.

Rodman (1986) has presumed that the unoccupied habitat can act as a factor to promote the successful infiltration of Cakile edentula.

In coastal regions of Northeast Asia including the coast lines of the East Sea, the ecological niche of plant 
Table 1 Structured table of the Cakile edentula vegetation in Korea

A: Calystegio soldanellae-Salsoletum komarovi, B: Elymo-Caricetum kobomugi, C: Carex pumila community, D: Calystegia soldanella community

$$
\begin{array}{lllllllllllllllllll}
1 & 2 & 3 & 4 & 5 & 6 & 7 & 8 & 9 & 10 & 11 & 12 & 13 & 14 & 15 & 16 & 17 & 18 & 19
\end{array}
$$

Scientific Name

A

B

C D

Cakile edentula

\begin{tabular}{|c|c|c|c|c|c|c|}
\hline 7 & 6 & 8 & 4 & 5 & & 4 \\
\hline 4 & 2 & 4 & 8 & 1 & & 6 \\
\hline 6 & 5 & 6 & 5 & 5 & & 1 \\
\hline . & 1 & & 1 & & 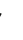 & . \\
\hline . & 4 & & 3 & 1 & . & 3 \\
\hline 1 & & 1 & & & & 8 \\
\hline
\end{tabular}

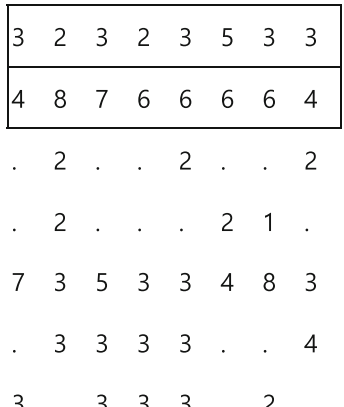

Glehnia littoralis

. 2. $1.25 \cdot 2$

Ixeris repens

1.2

44

$3.2 \cdot 11 \cdot 6$

Lathyrus japonicus

. $11.4 \quad 4 \quad 2.4$

3.2 .22 .

Zoysia sinica

. 2... 2 .

$\begin{array}{lllll}5 & 3 & 3 & 6 & 2\end{array}$.

Cuscuta pentagona

$22 \cdot 32$

Oenothera biennis

. 1.211 .

Setaria viridis

. . 1. 2

Chenopodium album var. centrorubrum

Artemisia capillaris

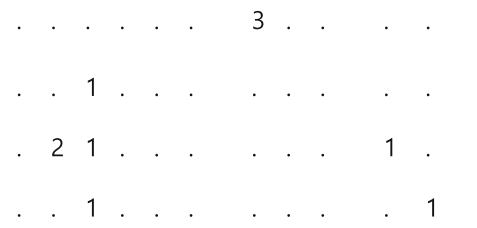

Chenopodium ficifolium

Diodia teres

$\cdot 1 \cdot$.

No.3 Digitaria sp 1, Xanthium canadense 1, No.5 Ambrosia artemisiifolia 1, Phytolacca americana 1, No.11 Artemisia princeps 1, No.13 Commelina communis 1, Scutellaria strigillosa 1. No.14 Imperata cylindrica var. koenigii 2, No.16 Linaria japonica 3, No.17 Cynodon dactylon 4.

No. date, Latitude, Longitude, area(m2), altitude, slope:

No.01 2016.08. 09. E 3830 14.16, N 12825 33.16, 25, 2, 1, No.2 2016.08.09., E 3829 25.67, N 12825 44.80, 20, 3, 2, No.03 2016.08.10., E 3814 57.37, N 12834 08.63, 15, 3, 1. No.4 2016.08.10., E 3808 08.92, N 12837 07.76, 50, 3, 0. No.05 2016.08.10., E 3819 31.92, N 12831 41.52, 25, 3, 0. No.6 2016.08.10., E 3806 29.66, N 12838 36.25, 25, 1, 0. No.07 2016.08.10., E 3755 31.80, N 12847 55.02, 150, 5, 2. No.8 2016.08.09., E 3820 04.69, N 12831 29.04, 100, 1, 1. No.09 2016.08.10., E 3861 39.34, N 12843 06.53, 100, 3, 1 No.10 2016.08.09., E 3820 05.08, N 12831 22.96, 100, 2, 1. No.11 2016.08.10., E 3814 55.29, N 12834 10.09, 25, 1, 1. No.12 2016.08.11., E 3759 04.64, N 12845 07.51, 100, 3, 4. No.13 2016.08.10., E 3741 31.95, N 12901 56.40, 300, 3, 1. No.14 2016.08.10., E 3746 38.85, N 12856 27.98, 750, 5, 3. No.15 2016.08.10., E 3746 54.0, N 12856 07.3, 500, 5, 5. No.16 2016.08.10., E 3749 24.02, N 12853 08.20, 100, 5, 5. No.17 2016.08.10., E 3754 54.70, N 12848 44.57, 100, 5, 10 No.18 2016.08.10., E 37 54 59.73, N 12848 38.01, 1000, 5, No.19 2016.08.10., E 3756 14.07, N 12849 14.50, 950, 2, 3

species belonging to the genus of Cakile edentula (Cakile Mill.) has been historically unestablished.

By considering comprehensive factors including climatic elements and non-biological elements (such as empty habitats), Cakile edentula seems to be a successful invader infiltrated into the coast of Northeast Asia.

Korea and Japan share similar characteristics of the infiltration and propagation of Cakile edentula. In terms of 
Table 2 r-NCDI value in coastal sand dune vegetation

\begin{tabular}{|c|c|c|c|c|c|c|c|c|}
\hline \multicolumn{3}{|c|}{$\begin{array}{l}\text { A: Calystegio soldanellae-Salsoletum } \\
\text { pumila community, } \\
\text { D: Calystegia soldanella community }\end{array}$} & komarovi & \multicolumn{5}{|c|}{ i, B: Elymo-Caricetum kobomugi, C: Care } \\
\hline \multirow[b]{2}{*}{ Scientific Name } & \multicolumn{2}{|l|}{ A } & \multicolumn{2}{|l|}{$B$} & \multicolumn{2}{|l|}{ c } & \multicolumn{2}{|l|}{$D$} \\
\hline & $\bar{T}$ & $R$ & $T$ & $R$ & $T$ & $\mathrm{R}$ & $T$ & $R$ \\
\hline Cakile edentula & 100.00 & & 54.50 & & 43.80 & & 51.10 & \\
\hline Calystegia soldanella & 74.30 & 38.98 & 33.30 & 36.26 & 62.50 & 42.47 & 100.00 & 100.00 \\
\hline Salsola komarovii & 91.40 & 100.00 & 3.03 & 0.29 & 18.80 & 3.70 & 4.79 & 2.33 \\
\hline Carex kobomugi & 1.90 & . & 100.00 & 84.12 & & . & 3.99 & \\
\hline Elymus mollis & 11.40 & 2.42 & 24.20 & 100.00 & 9.38 & 0.68 & 76.60 & 0.37 \\
\hline Carex pumila & 7.14 & 15.99 & 12.10 & 0.50 & 100.00 & 100.00 & 21.30 & 2.24 \\
\hline Glehnia littoralis & 2.86 & & 21.20 & 7.62 & 6.25 & 5.48 & 18.60 & 1.87 \\
\hline Ixeris repens & 2.86 & 0.81 & 24.20 & 43.00 & . & 20.14 & 17.30 & 5.04 \\
\hline Lathyrus japonicus & 8.57 & & 3.03 & 6.45 & 12.50 & 0.41 & 9.57 & 0.98 \\
\hline Zoysia sinica & 0.95 & . & 3.03 & & . & & 25.30 & \\
\hline Oenothera biennis & 5.71 & & 1.52 & & & & . & \\
\hline Cuscuta pentagona & 17.10 & . & & & . & & 0.27 & \\
\hline $\begin{array}{l}\text { Chenopodium album } \\
\text { var. centrorubrum }\end{array}$ & & 0.81 & 4.55 & & & & 2.66 & 0.09 \\
\hline Artemisia capillaris & 0.48 & . & & 0.05 & . & & 2.13 & 0.09 \\
\hline Setaria viridis & 2.86 & . & & & . & . & 0.27 & \\
\hline Chenopodium ficifolium & m2.86 & . & & & 3.13 & & . & \\
\hline Diodia teres & 0.48 & . & & & 3.13 & & . & \\
\hline Artemisia princeps & & 0.27 & & 0.02 & 3.13 & & . & \\
\hline Digitaria ciliaris & . & 30.24 & & 0.19 & . & 1.10 & . & 5.88 \\
\hline Atriplex subcordata & . & . & & & & . & & \\
\hline Cynodon dactylon & & 0.54 & & 0.57 & & 0.55 & & 7.18 \\
\hline Corispermum stauntoni & & 0.27 & & 0.19 & & 1.64 & & 0.37 \\
\hline Zoysia macrostachya & & 2.02 & & 2.58 & & 0.27 & & \\
\hline Cynodon dactylon & & & & & & & 1.06 & \\
\hline Linaria japonica & & & & & & & 0.80 & \\
\hline $\begin{array}{l}\text { Imperata cylindrica var } \\
\text { koenigii }\end{array}$ & & & & & & & 0.53 & \\
\hline Scutellaria strigillosa & & & & & & & 0.27 & \\
\hline Commelina communis & & & & & & & 0.27 & . \\
\hline Ambrosia artemisiifolia & 0.48 & & & & & & & \\
\hline Xanthium canadense & 0.48 & & & & & & & . \\
\hline Poa sp. & 0.48 & & & & & & & \\
\hline $\begin{array}{l}\text { Chenopodium } \\
\text { acuminatum }\end{array}$ & $\cdot$ & 0.27 & & & & . & & 0.09 \\
\hline Humulus japonicus & & & & & & & & \\
\hline $\begin{array}{l}\text { Ischaemum } \\
\text { anthephoroides }\end{array}$ & & & & & & 0.27 & & 0.65 \\
\hline Zoysia sinica & & & & & & 0.27 & & 0.19 \\
\hline Argusia sibirica & & & & & & & & \\
\hline Conyza canadensis & & & & & & & & \\
\hline Echinochloa crus-galli & & 0.27 & & & & & & \\
\hline Artemisia scoparia & & 0.13 & & & & & & \\
\hline Persicaria hydropiper & & 0.13 & & & & & & \\
\hline Cuscuta chinensis & & & & & & & & 3.92 \\
\hline Cnidium japonicum & & & & & & & & 0.28 \\
\hline Plantago camtschatica & & & & & & & & 0.09 \\
\hline Equisetum arvense & & & & & & & & 0.09 \\
\hline Vitex rotundifolia & & & & & & 0.27 & & \\
\hline Centipeda minima & & & & & & 0.27 & & \\
\hline Rosa rugosa & & & & 0.10 & & & & \\
\hline Trifolium repens & & & & & & & & 0.00 \\
\hline
\end{tabular}

$T$ this study, $R$ reference (Han 2013) spatial propagation of Cakile edentula in coastal dunes, vegetation of Cakile edentula was observed in the area extending from the top of the high-water line exposed to effects of sea waves to the front face of the foredune (Fig. 2).

In Japan, higher rate of appearance of Cakile edentula in areas closer to coast lines has been reported (Taira and Hiroko 2006).

Cakile edentula grows on the front of the foredune. It has been reported that Cakile edentula does not grow in the shrubby vegetation of rosa rugose (Rosetalia rugosae Ohba, Miyawaki et Tx. 1973) (Taira and Hiroko 2006).

\section{Conclusions}

Results of a previous study revealed that the central area of a beach had the highest coverage of Cakile edentula in North America (Barbour et al. 1976). In Northeast Asia, Cakile edentula inhabits coastal dunes. It is characterized by its frequent appearance mostly in front of coastal dunes that are highly disturbed (Fig. 3).

In Australia, although Cakile edentula has been found to coexist with some plant species such as Arctotheca nivea and Atriplex billardieri, Cakile edentula grows solely in most coastal areas (Sauer 1965; Smith 1973; Beadle 1981; Heyligers 1984).

It has been concluded that plants belonging to the genus of Cakile cannot replace indigenous taxonomic groups in the invaded area with few or no potential competitors therein (Rodman 1986).

However, in Northeast Asia, Cakile edentula has infiltrated into coastal dunes. It faces competition with representative coastal vegetation of saltwort (barilla) and Asian sand sedge (Doing 1985), thus changing species composition inside each community.

In Japan, Cakile edentula grows in the Cakile edentula-saltwort (barilla) community, sea wheatgrass community, and Lathyrus japonicas-sea wheatgrass community belonging to classes of saltwort (barilla) (Salsoletea komarovii Ohba, Miyawaki et Tx. 1973) and coastal glehnia (Glehnietea littoralisOhba, Miyawaki et Tx. 1973) (Taira and Hiroko 2006).

Similar to cases in Korea, Cakile edentula shows its high dominance in the Cakile edentula-saltwort (barilla) community but the lowest frequency in the Lathyrus japonicas-sea wheatgrass community (Taira and Hiroko 2006).

Cakile edentula seems to share habitat with saltwort (barilla) in Korea and Japan where it directly competes with them.

Currently, studies that identify negative effects of Cakile edentula infiltration on local ecosystems are unavailable. Therefore, it is necessary to focus on issues related to the destruction of indigenous landscapes or to its competition with indigenous species according to propagation of Cakile edentula. 

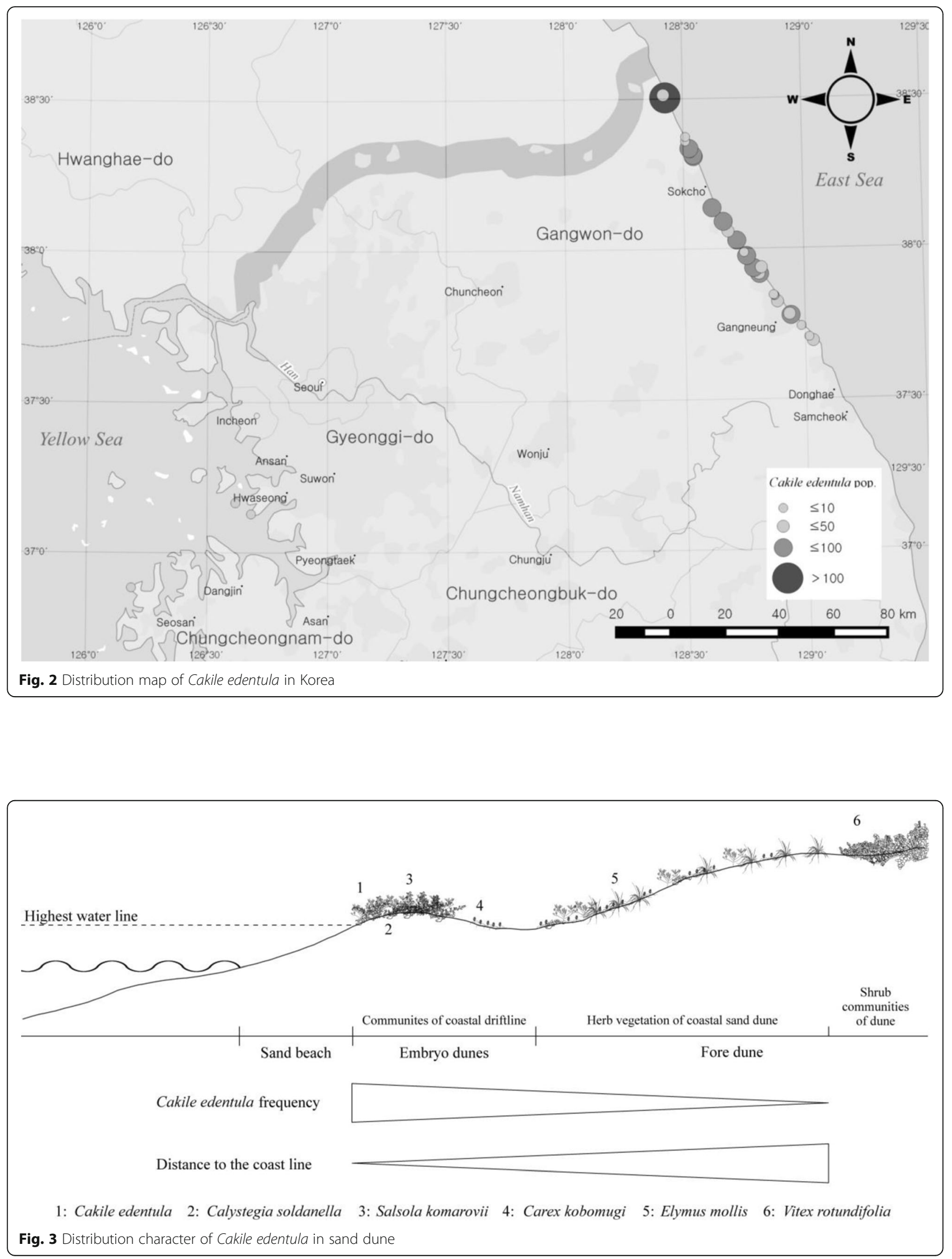
Consequently, Cakile edentula infiltrated into coastal dunes in Northeast Asia competes directly with the saltwort (barilla) growing in sites highly disturbed by effects of eutrophication or sea waves. It is also exposed to changes in intracommunity species composition and various issues such as destruction of indigenous coastal landscapes.

The propagation of Cakile edentula continues. Integrated studies on ecosystems exposed to the infiltration of Cakile edentula seem necessary to protect coastal dunes by using possible measures of ecological approaches, insects, cycle of matter, and so on.

\section{Acknowledgements}

This study was conducted through the studies of the "Investigating Ecological Risk of Alien Species (NIE-2016-08)" and "National Investigation of the Habitats of Nutria (Myocastor coypus) (NIE-2016-08)".

\section{Funding}

This study was supported by Ecological Studies of Alien Species and the study on the Inhabitation Status of Nutria (Myocastor coypus) through the Ministry of Environment (NIE-2016-8).

\section{Authors' contributions}

TBR carried out the field studies and drafted the manuscript. DGK, DHC, JHL, and DHL researched the field. NYK conceived of the study, participated in its design, and helped to draft the manuscript. All authors read and approved the final manuscript.

\section{Ethics approval and consent to participate}

Not applicable

\section{Consent for publication}

Not applicable

\section{Competing interests}

The authors declare that they have no competing interests.

\section{Publisher's Note}

Springer Nature remains neutral with regard to jurisdictional claims in published maps and institutional affiliations.

Received: 22 March 2018 Accepted: 14 June 2018

Published online: 13 July 2018

\section{References}

Asai, Y. (1983). About new naturalized plant demon hammer Japanese radish of North American origin. The Journal of Japan Botany, 57(6), 187-191.

Baker, H. G. (1965). In H. G. Baker \& G. L. Stebbins (Eds.), Characteristics and modes of origin of weeds. The genetics of colonizing species (pp. 147-172). New York: Academic Press.

Barbour, M. G., De Jong, T. M., \& Johnson, A. F. (1976). Synecology of beach vegetation along the Pacific coast of the United States of America: a first approximation. Journal of Biogeography, 3, 55-69.

Barbour, M. G., \& Rodman, J. E. (1970). Saga of the west coast searockets: Cakile edentula ssp. californica and C. maritima. Rhodora, 70, 370-386.

Beadle, N. C. W. (1981). The vegetation of Australia (pp. 606-608). Cambridge University Press

Becking, R. W. (1957). The Zürich-Montpellier school of phytosociology. Botanical Review, 23, 411-488.

Braun-Blanquet, J. (1965). Plant sociology. The study of plant communities (Transl. by G.D. Fuller and H.S. Conard). New York.

Chapman, V. J. (1976). Coastal vegetation. Oxford: Pergamon Press.

Cousens, R. D., Ades, P. K., Mesgaran, M. B., \& Ohadi, S. (2013). Reassessment of the invasion history of two species of Cakile (Brassicaceae) in Australia. Cunninghamia, 13, 275-290.
Cousens, R. D., \& Cousens, J. M. (2011). Invasion of the New Zealand coastline by European sea-rocket (Calile maritima) and American sea-rocket (Cakile edentula). Invasive Plant Science and Management, 4, 260-263.

Doing, H. (1985). Coastal fore-dune zonation and succession in various parts of the world. In Ecology of coastal vegetation (pp. 65-75). Springer Netherlands.

Fukuda, T., Kato, Y., Sato, H., \& Taran, A. A. (2013). edentula (Brassicaceae) on the beaches of Kunashiri and Etorofu Islands—-the first record for the species from the Kuril Islands. Journal of Japanese Botany, 88, 124-128.

Han, Y. H. (2012). Coastal sand dune vegetation of the East Sea. Daegu: Master's thesis, Catholic University of Daegu (In Korean with English abstract).

Harper, J. L. (1965). In H. G. Baker \& G. L. Stebbins (Eds.), Establishment, aggression and cohabitation in weedy species. The genetics of colonizing species (pp. 243268). New York: Academic Press.

Harper, J. L. (1977). Population biology of plants. London: Academic Press.

Hayasaka, D., \& Fujiwara, K. (2006). Human activities and environmental factors determining vegetation composition on the dry coastal sand dunes along the Shonan Coast, Kanagawa Prefecture. Journal of Japanese Society of Revegetation Technology, 32(2), 346-354.

Heyligers, P. C. (1984). Beach invaders. Australian Natural History, 21, 212-214.

Jung, Y. K, \& Kim, J. W. (1998). Coastal sand dune vegetation in Kyungpook province. Journal of Ecology and Environment, 21(3), 257-262 (In Korean with English abstract).

Kil, J. H., \& Lee, K. S. (2008). An unrecorded naturalized plant in Korea: Cakile edentula (Brassicaceae). Korean Journal of Plant Taxonomy, 38(2), 179-185.

Kim, J. W., \& Lee, Y. K. (2006). Classification and assessment of plant communities. Seoul: World Science, Inc.

Kim, J. W. \& Manyko, Y. I. (1994). Syntaxonomical and synchorological characteristics of the cool-temperate mixed forest in the southern SikhoteAlin, Russian Far East. Korean Journal of Ecology, 17(4), 391-413.

Kiyosue, Y., \& Asai, Y. (2009). Establishment of an alien plant species Cakile edentula (Cruciferae) in western Japan, with notes on the first record of the species in the area. Bulletin of the Tottori Prefectural Museum, 46, 49-50.

KMA (Korea Meteorological Administration). (2012). The climate atlas of Korea. Seoul: KMA.

KMA (Korea Meteorological Administration). (2017). Climate information. http:// www.kma.go.kr. Accessed 1 November 2017.

Masanori, A. (1996). Vegetation communities of the North Coast (Nakatsu, USA, Himeshima Is. and Kunisaki Peninsula) in oita Pref. Bulletin of Beppu University Junior College, 15, 1-16.

Maun, M. A., Boyd, R. S., \& Olson, L. (1990). The biological flora of coastal dunes and wetlands. 1. Cakile edentula( Bigel.)Hook. Journal of Coastal Research, 6, 137-156

Mulligan, G. A. (1965). Recent colonization by herbaceous plants in Canada. In H. G. Baker \& G. L. Stebbins (Eds.), The genetics of colonizing plants (pp. 127-146). New York: Academic Press.

Rodman, J. E. (1974). Systematics and evolution of the genus Cakile (Cruciferae). Contributions from the Gray Herbarium of Harvard University, (205), 3-146.

Rodman, J. E. (1986). Introduction, establishment and replacement of sea-rockets (Cakile, Cruciferae) in Australia. Journal of Biogeography, 13, 159-171.

Rollins, R. C. (1993). The Cruciferae of continental North America: systematics of the mustard family from the Arctic to Panama. Stanford University Press.

Sauer, J. (1965). Geographic reconnaissance of Western Australian seashore vegetation. Australian Journal of Botany, 13, 39-69.

Smith, G. G. (1973). A guide to the coastal flora of South-Western Australia. Handbook No. 10. Perth: Western Australian Naturalists' Club.

Taira, T., \& Hiroko, F. (2006). Emergence of alien plant species American sea rochet( Cakile edentula) on the sandy coast of Hokkaido Island, Japan. Vegetation Science, 33, 89-97( ).

Tüxen, R. (1973). Pflanzensoziologische Beobachtungen in Japan. Vegetatio, 1-2.

Weber, H. E., Moravec, J., \& Theurillat, J. P. (2000). International code of phytosociological nomenclature. 3rd edition. Journal of Vegetation Science, 11, 739-768.

Westhoff, V., \& van der Maarel, E. (1978). The Braun-Blanquet approach. In R. H. Whittacker (Ed.), Ordination and classification of communities (pp. 287-399). Hague, Boston, London: Dr. W Junk by Publisher.

Yoon, H. S., Park, S. Y., \& Yoo, C. I. (2010). Review of the functional properties and spatial distribution of coastal sand dunes in South Korea. Journal of Fisheries and Marine Sciences Education, 22(2), 180-194. 